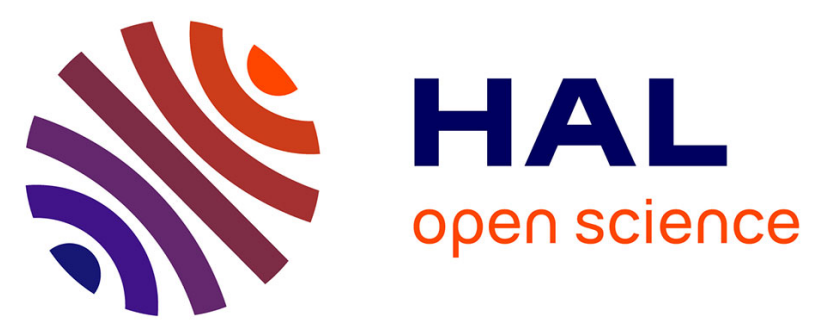

\title{
Towards a Sustainable Innovation Process: Integrating Lean and Sustainability Principles
}

\author{
Myrna Flores, Doroteja Maklin, Billy Ingram, Matic Golob, Christopher
}

Tucci, Andrea Hoffmeier

\section{- To cite this version:}

Myrna Flores, Doroteja Maklin, Billy Ingram, Matic Golob, Christopher Tucci, et al.. Towards a Sustainable Innovation Process: Integrating Lean and Sustainability Principles. IFIP International Conference on Advances in Production Management Systems (APMS), Aug 2018, Seoul, South Korea. pp.34-42, 10.1007/978-3-319-99704-9_5 . hal-02164912

\section{HAL Id: hal-02164912 \\ https://hal.inria.fr/hal-02164912}

Submitted on 25 Jun 2019

HAL is a multi-disciplinary open access archive for the deposit and dissemination of scientific research documents, whether they are published or not. The documents may come from teaching and research institutions in France or abroad, or from public or private research centers.
L'archive ouverte pluridisciplinaire HAL, est destinée au dépôt et à la diffusion de documents scientifiques de niveau recherche, publiés ou non, émanant des établissements d'enseignement et de recherche français ou étrangers, des laboratoires publics ou privés. 


\title{
Towards a Sustainable Innovation Process: Integrating Lean and Sustainability Principles
}

\author{
Myrna Flores ${ }^{1,2}$, Doroteja Maklin ${ }^{2}$, Billy Ingram ${ }^{3}$, \\ Matic Golob ${ }^{2}$, Christopher Tucci ${ }^{1}$, Andrea Hoffmeier ${ }^{4}$, \\ ${ }^{1}$ École Polytechnique Fédérale de Lausanne, Switzerland ${ }^{2}$ Lean Analytics Association, Swit- \\ zerland ${ }^{3}$ Interface Inc., Georgia, USA ${ }^{4}$ SHERPA Sustainability Institute, Colorado, USA \\ myrna.floresdepfl.ch
}

\begin{abstract}
Many companies are heavily investing resources to innovate faster and smarter in order to gain or retain a competitive advantage. Nevertheless, defining and deploying a sustainable innovation vision still represents a challenge to most companies, as a deep change of mindset is required to reflect going beyond the design, development, production and distribution of new products, to also consider their disposal, recycling or reuse, as part of their end-to-end product life cycle. Therefore, this paper aims to: 1) highlight the relevance of including lean and sustainability principles in the early design and conceptualization phases, 2) explain how lean and sustainability can bring benefits when applied as an integrated system considering three axes: the economic, the social and the environmental, and 3) share a case study providing insights of a successful application.
\end{abstract}

Keywords: Sustainability, Green, Lean, Innovation, Product Development

\section{Introduction}

Ever since humans evolved from Hominidae, we have constantly been looking for new products and services to evolve and solve day-to-day challenges. Companies, governments and users continuously strive for innovative products to make our lives simpler, more effective and easier. However, not many consider the effects such products/services have through their lifecycle and their impact on the economy, society and the environment. During the innovation process, products and services are designed to satisfy customer needs, and lean and sustainability thinking are a vital part of the process. There are numerous successful and detailed examples of how companies have applied lean to eliminate waste and decrease costs both in manufacturing and services organizations. But only very few industrial cases show evidence of how lean and sustainability are applied in industrial settings since the very early stages of the conception of new products, thus taking into consideration the end-to-end life cycle.

The first thing that comes to mind when linking lean and sustainability is to eliminate waste or use less resources such as energy to reduce costs. However, sustainable innovation brings much more than just economic benefits from waste reduction, since it also focuses on the impact on the environment and society in an integrated system. 


\section{Research method}

The Lean Analytics Association together with EPFL started the yearly Lean Product Development Best Practices Discovery Project in 2015. Eighteen companies have joined since, and company cases have been collaboratively developed, some of which were published in a book [5]. Through this paper, the authors aim to answer the following research questions:

\section{How are lean innovation and sustainability interconnected?}

2. Which best practices can be identified in the industry that could increase awareness about the relevance of considering lean and sustainability when developing new products?

The approach followed six main research steps. Firstly, the need was identified and the research question specified. Secondly, the state-of-the-art literature review was conducted. The literature review aimed to identify the lean and sustainability best practices applied in innovation process. Thirdly, the questionnaire was developed and interviews with the innovation leaders conducted. The interview answers were analyzed and documented to result in research publications. The last step aims to enable the industry and academia to learn from the findings and innovate greener.

\section{$3 \quad$ Lean and Sustainability}

\subsection{Lean Thinking}

The lean concept observed and explored in Japanese companies was expanded to a comprehensive philosophy by Womack and Jones [10]. In their book Lean thinking: Banish waste and create wealth in your corporation, they defined the five principles of lean thinking, as shown in Figure 1.

\begin{tabular}{ll} 
Value & $\begin{array}{l}\text { Specify what creates value from the customer's } \\
\text { perspective (new product) }\end{array}$ \\
\hline The value stream & Identify all the steps along the process chain \\
\hline Flow & Make the value process flow: eliminate waste \\
\hline Pull & Make only what is needed by the customer \\
\hline $\begin{array}{l}\text { Perfection/ } \\
\text { Continuous }\end{array}$ & $\begin{array}{l}\text { Strive for perfection by continually attempting to } \\
\text { Improvement }\end{array}$ \\
\hline
\end{tabular}

Fig. 1. Five lean principles (adapted from [10])

\subsection{Lean Innovation}

Lean innovation is the application of lean thinking to the End-to-End Innovation process, as shown in Figure 2. It focuses on value creation, the provision of a knowledge environment and continuous improvement, which together encourage collaborative and sustainable innovation [5]. 


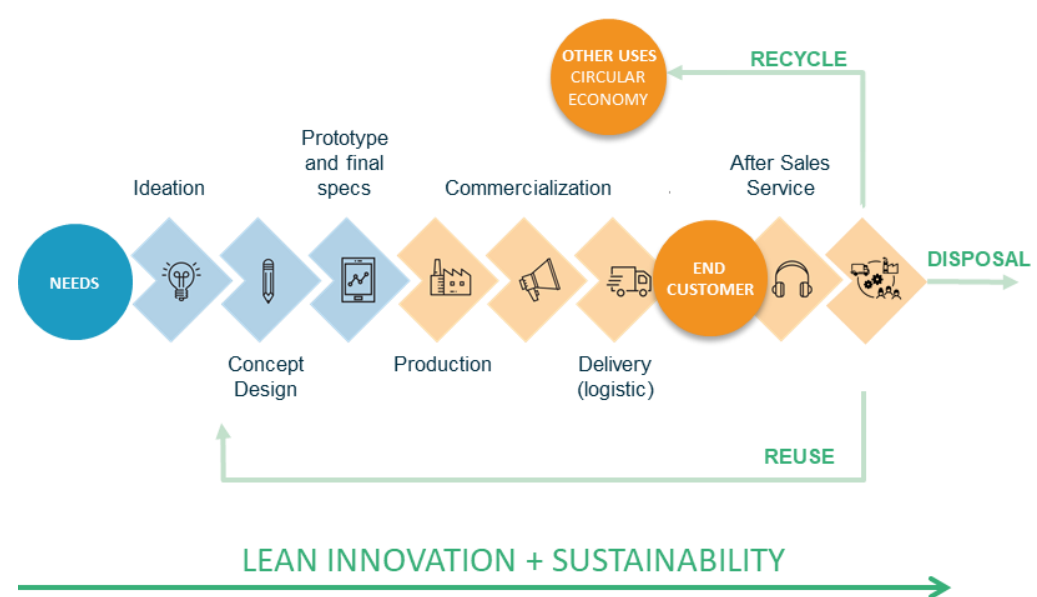

Fig. 2. Lean Innovation and sustainability in the End-to-End innovation process

Lean efforts have focused mostly towards production and other transactional processes where waste was visible and savings in terms of cost were immediately noticeable. Figure 3 illustrates the significantly higher influence of the product design in comparison to the other phases. Therefore, if during the product design, the right decisions are made regarding design, processes and sustainability and the correct deliverables are forwarded, considerable waste will be avoided in the later stages and the whole process will become more efficient. Not only the efficiency but also the forecast of the entire product/service lifecycle with circular vision is determined at the design stage.

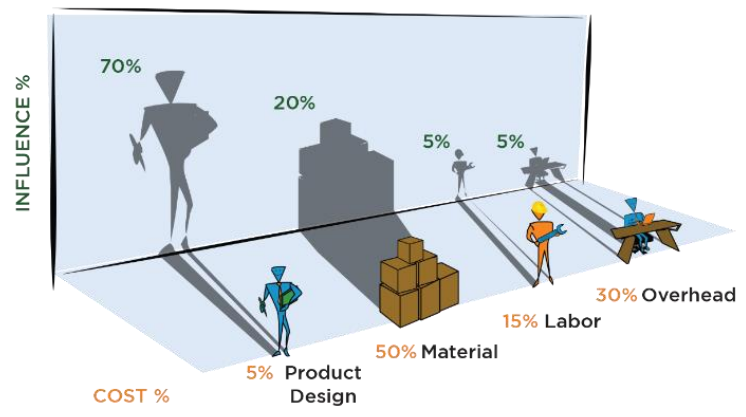

Fig. 3. Who casts the biggest shadow (adapted from [7])

By incorporating Design for Sustainability principles, lean innovation supports and enables waste elimination through the entire value chain and it does not only bring economic benefits to companies, but also to the environment and society. The human factor and their skills are significant enablers towards lean and sustainable innovation. To be able to address sustainability challenges and design products for a green future, the employees in industry require training to develop a new mindset that enables them to integrate into their daily operations not only the economic aspect but also the environmental and social elements [4]. 


\subsection{Sustainability}

Sustainability aims to develop and sustain the environmental, social and economic circumstances that enable humans to co-exist with nature in "productive harmony" both in the present and the future $[1,10]$. A process where sustainability (environmental, social and economic as shown in figure 4) considerations are integrated into company systems from the idea generation through to research and development (R\&D) and commercialization, is called sustainable innovation. This applies to products, services and technologies, as well as new business and organization models [2]. Furthermore, the definition of social responsibility (SR) was established in 2010 through the ISO 26000 and is foundational to our methods [3]. The SR Principle "Respect for Stakeholder Interests" is examined.

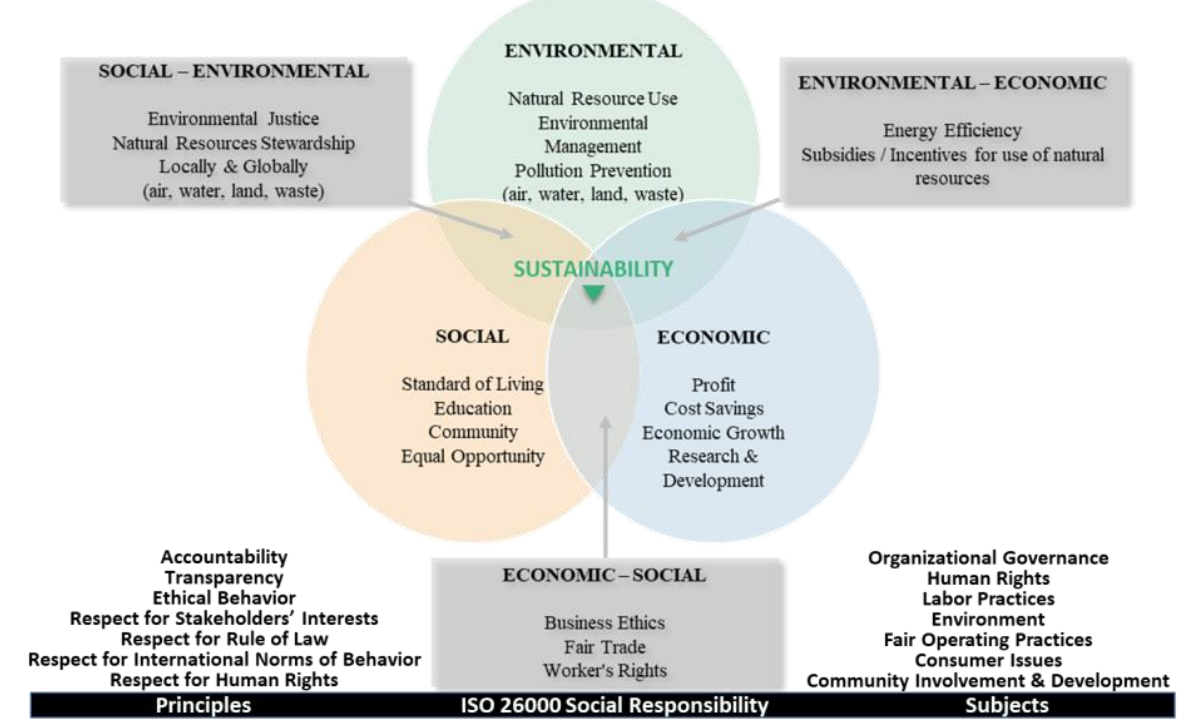

Fig. 4. Aspects of Sustainability (adapted from [8]; addition of ISO 26000)

\section{$4 \quad$ Lean Innovation Model incorporating sustainability aspect}

The Lean Innovation Model was developed to provide as a structured guide to create an integrated vision for the companies to start or continue their lean product development journey [5]. It is a framework that incorporates four main building blocks: 1 . Strategy and Performance, 2. Skilled People and Collaboration, 3. Efficient Process and Knowledge-based Environment, 4. Continuous Improvement and Change. Each building block is represented by three enablers, giving a total of twelve enablers, as represented in Table 1. The model integrates both the technical enablers, as well as the "soft" aspects of skills, collaboration and leadership which are indispensable for a successful implementation. One of the important enablers is also 7. Sustainable Innovation Process. 
Table 1. The Lean Innovation Model [5]

\begin{tabular}{|c|c|c|c|}
\hline $\begin{array}{l}\text { 1. STRATEGY } \\
\text { AND } \\
\text { PERFORMANCE }\end{array}$ & 1. Customer Value & $\begin{array}{l}\text { 3. EFFICIENT } \\
\text { PROCESS AND } \\
\text { KNOWLEDGE- } \\
\text { BASED } \\
\text { ENVIRONMENT }\end{array}$ & $\begin{array}{l}\text { 7. Sustainable innova- } \\
\text { tion process }\end{array}$ \\
\hline & $\begin{array}{l}\text { 2. Strategy and Lead- } \\
\text { ership Commitment }\end{array}$ & & $\begin{array}{l}\text { 8. Lean thinking tools and } \\
\text { methods }\end{array}$ \\
\hline & 3. Track Performance & & $\begin{array}{l}\text { 9. Co-create, share and } \\
\text { reuse knowledge }\end{array}$ \\
\hline \multirow[t]{3}{*}{$\begin{array}{c}\text { 2. SKILLED } \\
\text { PEOPLE AND } \\
\text { COLLABORATION }\end{array}$} & 4. Human Skills & $\begin{array}{l}\text { 4. CONTINUOUS } \\
\text { IMPROVEMENT } \\
\text { AND CHANGE }\end{array}$ & $\begin{array}{l}\text { 10. Continuous Improve- } \\
\text { ment System }\end{array}$ \\
\hline & 5. Chief Engineer & & $\begin{array}{l}\text { 11. Internal and External } \\
\text { partnerships }\end{array}$ \\
\hline & $\begin{array}{l}\text { 6. Cross-functional } \\
\text { Collaboration }\end{array}$ & & $\begin{array}{l}\text { 12. Communicate, man- } \\
\text { age and reward change }\end{array}$ \\
\hline
\end{tabular}

A truly sustainable lean innovation process is supported by activities during the whole End-to-end innovation phases. Table 2 outlines different innovation phases and which sustainability focused activity areas contribute to each one of them.

Table 2. Sustainable lean innovation phases and sustainability focus areas

\begin{tabular}{|c|c|}
\hline $\begin{array}{l}\text { Innovation } \\
\text { Phases }\end{array}$ & Sustainability focus areas \\
\hline Engagement & - Stakeholder analysis and respect for stakeholder interests \\
\hline Ideation & $\begin{array}{l}\text { - Considering stakeholder interests throughout the entire } \\
\text { product lifecycle: aiming to reduce } \mathrm{CO}_{2} \text { footprint \& any } \\
\text { harm end-to-end }\end{array}$ \\
\hline Concept Design & $\begin{array}{l}\text { - Reusing some of the components or disposed products } \\
\text { - Using recycled materials \& reducing material use } \\
\text { - Assessing social impact on all stakeholders }\end{array}$ \\
\hline $\begin{array}{l}\text { Prototype and final } \\
\text { specs }\end{array}$ & $\begin{array}{l}\text { - Creating a product that will produce minimal waste } \\
\text { - Creating a product that will consume little energy } \\
\text { - Ensuring health and safety requirements for all stakeholders }\end{array}$ \\
\hline Production & $\begin{array}{l}\text { - Reducing energy consumption and using renewable energy } \\
\text { - Considering workers as stakeholders } \\
\text { - Reducing production waste }\end{array}$ \\
\hline Commercialization & $\begin{array}{l}\text { - Green marketing [9] } \\
\text { - Value-driven model elevates stakeholders/society } \\
\text { - Consumer awareness of all types of impact (includes envi- } \\
\text { ronment) }\end{array}$ \\
\hline Delivery & $\begin{array}{l}\text { - Using green logistics and reducing the } \mathrm{CO}_{2} \text { footprint } \\
\text { - Promoting local sourcing: engaging local stakeholders }\end{array}$ \\
\hline After Sales Service & - Promoting responsible use: repairs vs replacements \\
\hline $\begin{array}{l}\text { Disposal/ } \\
\text { Recycling/Reuse }\end{array}$ & $\begin{array}{l}\text { - Encouraging users and other relevant stakeholders to recycle, } \\
\text { safely dispose or reuse products }\end{array}$ \\
\hline
\end{tabular}


practices have been identified and documented. In the third building block of the Lean Innovation Model, Efficient Process and Knowledge Based Environment, eleven best practices were consolidated from the 18 companies, six of which were categorized as "common" (well-known in the industrial innovation processes) and five as "emerging practices" (identified in less than five companies)as illustrated in figure 5. As observed, although the 18 interviewed companies have a clear product development process, there is currently poor integration of a sustainability strategy in innovation. Only three have so far integrated the sustainability vision into the product development practice. Therefore, sustainable innovation is still considered as one emerging best practice in lean innovation.

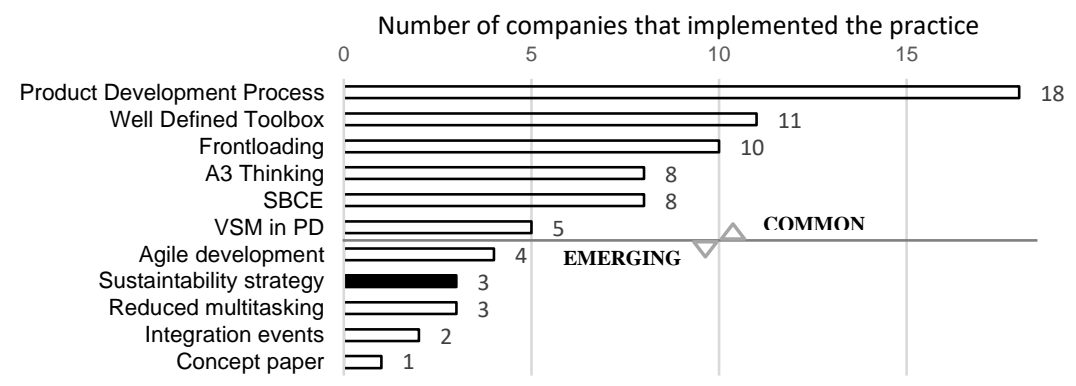

Fig. 5. Emerging and common best practices identified in the Efficient Process and Knowledge Based Environment building block of the Lean Innovation model $(\mathrm{N}=18)$ [5]

The following section will provide more details about the practices of Interface, since it is the strongest of the three identified companies that continuously pursues the integration of its sustainability strategy into the innovation process.

\section{Case Study: Interface Inc. - Implementing the Mission Zero Strategy}

Interface is the world's largest manufacturer and marketer of modular carpet, headquartered in LaGrange, Georgia, USA. The company maintains its position among top sustainability leaders as a result of the company's focus on sustainability through its Mission Zero strategy which is aligned with the people, process, product, place and profits. Mission Zero was proposed under the leadership of Ray C. Anderson (1994) and its focus is "to be the first company that, by its deeds, shows the entire industrial world what sustainability is in all its dimensions: people, process, product, place and profits - by 2020 — and in doing so, to become restorative through the power of influence" [6].

To accomplish this latter goal by 2020 and guide employees through the transformation, Interface developed the Mount Sustainability framework. Seven Fronts of Mount Sustainability were identified and placed on the mountain framework to remind employees of the fronts through which the company needs to pass to reach the top of the mountain before 2020 . 
Table 3. Interface Mount Sustainability's seven fronts and targets

\begin{tabular}{|l|l|}
\hline Front 1: Eliminate Waste & $\begin{array}{l}\text { Eliminate all forms of waste in every area of the business - } \\
\mathbf{\$ 1 6} \text { million in operational cost avoidance }\end{array}$ \\
\hline Front 2: Benign Emissions & $\begin{array}{l}\text { Eliminate toxic substances from products, vehicles and facil- } \\
\text { ities - } \mathbf{\$ 5 0} \text { million inventory reduction }\end{array}$ \\
\hline $\begin{array}{l}\text { Front 3: Renewable en- } \\
\text { ergy }\end{array}$ & Operate facilities with $\mathbf{1 0 0 \% \text { renewable energy }}$ \\
\hline Front 4: Closing the Loop & $\begin{array}{l}\text { Redesign processes and products to close the technical loop } \\
\text { using recycled and bio-based materials } \\
\text { - Recycled and bio-based raw material content increased } \\
\text { from 50\% to 75\%. }\end{array}$ \\
\hline $\begin{array}{l}\text { Front 5: Efficient } \\
\text { transportation }\end{array}$ & $\begin{array}{l}\text { Transport people and products efficiently to eliminate waste } \\
\text { and emissions - Reduce transportation costs by 30\%. }\end{array}$ \\
\hline Front 6: Sensitizing & $\begin{array}{l}\text { Create a culture that uses sustainability principles to improve } \\
\text { the lives and livelihood of all stakeholders } \\
\text { - Connect customers and vendors through Interface, pos- } \\
\text { itively influencing both. }\end{array}$ \\
\hline $\begin{array}{l}\text { Front 7: Redesign Com- } \\
\text { merce }\end{array}$ & $\begin{array}{l}\text { Create a new business model that demonstrates and supports } \\
\text { the value of sustainability-based commerce - Disrupt com- } \\
\text { petitors and raise customer expectations in the industry. } \\
\text { Sell 30\% more at } \mathbf{1 5 \%} \text { higher margins. }\end{array}$ \\
\hline
\end{tabular}

The entire organization is committed to continuous improvement, and sustainability became a common vision which is deeply embedded in employees' behavior as part of their day-to-day focus. As a consequence, two key projects have shown the positive results and impact of Sustainable Innovation.

Net Works is a collaborative project between the Zoological Society of London, Aquafl (yarn producer) and Interface. An innovative, cross-sector initiative, was designed to tackle the growing environmental problem of discarded fishing nets in the world's coastal communities. Local fishermen in the Philippines usually discarded fishing nets that got tangled whilst out in the sea. The nets polluted the sea water and endangered the wildlife in the local area. The companies offer fishermen payment for the waste fishing nets, if they are brought onshore. Fishing nets are then recycled to produce yarn to be used for the production of new carpet tiles. Whilst benefiting the society by providing income for fishermen, the initiative helps educate the local society about the dangers of water pollution, and maintain the environment clean. Interface fulfils Mission Zero's goal to source $100 \%$ recycled materials for its carpet tiles. This can be referred to Circular Economy, in which one sector recycles the waste from another.

TacTiles ${ }^{\circledR}$ is Interface's carpet tile installation system that integrates lean thinking and sustainability to reduce waste and provide value to the customer. TacTiles are small adhesive-backed squares that connect carpet tiles securely to form a floor that "floats" for improved flexibility, easier replacement and long-term performance without permanent adhesion to the subfloor. TacTiles are a result of research and design using lean and sustainability concepts to reduce the environmental footprint and waste generated during the process, to save space and to cut transport costs compared to previously used glue adhesives. TacTiles have been imitated and adopted across the industry as a good practice of carpet tile installation, leading by example. 


\section{Conclusions}

Although Lean and Sustainability have been applied in many organizations, their integration to design and develop new products still represents a challenge. The sustainable innovation approach will enable companies: 1) to develop new products and services, while not only envisioning economic returns, but also integrating the impact those innovations have on the environment and society, 2) to widen the scope, going from the ideation phase to the recycling, reuse or disposal of all products, 3) to achieve innovative leaps by taking all stakeholders into consideration. This paper provided evidence of a successful industrial case, in which a carpet producing company has defined and deployed a strategy that successfully integrates lean and sustainability considering the end-to-end innovation process providing economic returns but also impacting the environment and the society, taking care of the Earth's resources for future generations.

\section{$7 \quad$ References}

1. Ayman, A. E. O., Mayar, A.G., Nazirah, Z.A.: Lean Principles: An Innovative Approach for Achieving Sustainability in the Egyptian Construction Industry. Organization, technology and management in construction. An international Journal. 6 (1); 917-932 (2014).

2. Charter, M. and Clark, T.: Sustainable innovation key conclusions from sustainable innovation conferences 2003-2006, The Centre for Sustainable Design University College for the Creative Arts. www.cfsd.org.uk. Accessed 6 April 2018 (2007).

3. Duckworth H.A., Hoffmeier, A.: A Six Sigma Approach to Sustainability: Continual Improvement for Social Responsibility. CRC Press Taylor \& Francis Group (2015).

4. Flores, M., Canetta, L., Castrovinci, A., Pedrazzoli, P., Longhi, R. and Boër, C. R.: Towards an integrated framework for sustainable innovation, International Journal of Sustainable Engineering, 1:4, $278-286$ (2008).

5. Flores, M., Golob, M., Maklin, D., Tucci, C., Flores, K.: Lean product Development Best Practices: 10 industrial success stories. Lean Analytics Association. Carona, CH (2017).

6. Ingram, B. \& Design Studio Team. Interviewed by Maklin, D. and Flores, M. in LaGrange, USA (2015).

7. Munro and Associates: Who has the Biggest Shadow? www.leandesign.com/history-of-leandesign. Accessed 14 March 2016 (1989).

8. Rodriguez, M.A., Ricart, J.E. Sanchez, P.: Sustainable Development and the Sustainability of Competitive Advantage: A Dynamic and Sustainable View of the Firm. Creativity and Innovation Management, 11(3); 135-146 (2002).

9. United Nations Environment Programme: Design for sustainability. A Step-by-Step Approach. TU Delft and UNEP. Paris, France (2009).

10. USEPA: Basic Information The United States Environmental Protection Agency (USEPA). http://www.epa.gov/sustainability. Accessed 1 April 2018 (2009).

11. Womack, J. and Jones, D.: Lean Thinking: Banish Waste and Create Wealth in your Corporation. Simon \& Schuster UK Ltd, London, UK (1996). 